\title{
Hasnyálmirigy-sebészet a Semmelweis Egyetem I. sz. Sebészeti Klinikáján
}

\author{
HARSÁNYI LÁSZLÓ, TIHANYI TIBOR, MARJAI TAMÁS, BENKE MÁRTON, \\ SZÜCS ÁKOS, SZIJÁRTÓ ATTILA
}

Semmelweis Egyetem, I. sz. Sebészeti Klinika, Budapest

\begin{abstract}
„(...) magának a pankreasnak a klinikai diagnostikája a szerv rejtett helyzete és szövődött, sok szempontból még nem is teljesen tisztázott kórélettani vonatkozása miatt nem egyszer okoz nehézséget. (...) Még néhány évvel ezelőtt, amikor az acut pankreas-megbetegedések kórtanában a fertőzés elsődleges szerepe uralkodott, a minél korábbi feltárás (...) volt az általánosan ajánlott kezelési mód. Pólya vizsgálatai (...) e javallatnak alapjait megingatták, úgy, hogy a korai, sebészeti beavatkozás jogosultságáról és hasznáról ma a sebészet nézetei megoszlanak. (...) A rákos daganatok kezelésének egyetlen radikális módja a daganat kiirtása (...) A feji rész kiirtása oly szövődött beavatkozást igényel (...), hogy kivitele erősen legyengült betegen kilátástalan." Manninger Vilmos és Verebélÿ Tibor máig zsinórmértéknek tekinthető tankönyvük 1920-as kiadásában ${ }^{1}$ három gondolatban összegezték a hasnyálmirigy-sebészet aktuális állásának dilemmáit: a nehéz diagnosztika, a nem daganatos betegségek mütéti kezelésének optimális időzítése, valamint a pankreászdaganatos betegek egyetlen gyógyesélyét jelentő reszekciós mütétek sebésztechnikai, illetve általános perioperatív ellátási kérdései teszik a legnehezebb, legnagyobb kihívást jelentő - és „leghálátlanabb” - szakmai feladatok egyikévé a sebészi pankreatológiát. Mindennek ellenére az Üllői úti Sebészeti Klinika 111 éves történetének kiemelt szakmai céljai és kiemelten sikeres müködési területei közé sorolható, iskolateremtő jelentőségü a pankreászsebészet.
\end{abstract}

A hasnyálmirigy-sebészet a többi hasüri szerv sebészetéhez képest később indult fejlödésnek, és azokéhoz képest sokkal lassabban teljesedett ki. Walter Kausch ugyan már 1912-ben leírta a - két szakaszban elvégezhető - pancreato-duodenectomia (PD) technikáját, de Allen O. Whipple csak 1935-ben végzett sikeres PD-t. ${ }^{2}$ Az első közlemény, amely malignus hasnyálmirigy-daganat miatt egy lépésben elvégzett PD-ről számol be, csak 1937-ben jelent meg, Brunschwig tollából. ${ }^{3}$ A pankreászrák korszerű sebészi kezelésének valódi kezdetét tehát innen számíthatjuk. (A sokkal többet emlegetett 1899 -es Halsted-féle, ${ }^{4}$ valamint az 1935-ös Whipple-közleményben ugyan nagyon hasonló beavatkozásokról esik szó, de a mütéti javallatot eseteikben Vater-papilla-karcinóma képezte.) 1944-ben Watson beszámolt arról, hogy a pankreászfej eltávolítását a teljes gyomor, valamint a postpyloricus duodenum $\mathrm{kb} .1 \mathrm{~cm}$-es gyürüjének megőrzésével végezte el, majd a tápcsatorna folytonosságát végállású duodeno-jejunális anasztomózissal állította helyre. ${ }^{5}$ A sebészet történetét kevéssé ismerők számára is szinte magától értetődő, hogy az eljárás mint pylorus-megtartásos pancreato-duodenectomia (PPPD) ezek után más(ok)ról, Traversóról és Longmire-ről kapta szerzői nevét. Az eljárás a chronicus pancreatitis sebészetében széles körben teret nyert, bár több szerző úgy találta, hogy a PPPD után gyakori, elhúzódó gyomorürülési idő miatt késői eredményei a Whipple-mütéthez viszonyítva szerényebbek. ${ }^{6}$ A korai és hosszú távú eredmények javulásához hozzájárult a reziduális mirigyállomány gyomorba szájaztatásának terjedése, ami nagyrészt magyar kezdeményezésen alapuló modifikáció.

A ,minimális” (mérsékelt) invazivitású sebészi (MIS) technikák a tapasztalatok szerint az átlagosnál lassabban terjednek a pankreászsebészetben. A szervet hasi tükrözéssel Bernheim már 1911-ben biztosan megpillantotta, feltehetően elsőként, ${ }^{7}$ majd Gagner 1994-ben elvégezte az első laparoszkópos PPPD-t. ${ }^{8}$ Ez a két közlés tehát azt bizonyítja, hogy a sebésztechnikai innovációk meglepő gyorsasággal hatolhatnak be olyan területekre - így pl. a retroperitoneumba - is, ahol még „hagyományos” módszerekkel dolgozó sebészek sem rutinszerüen operálnak. A laparoszkópos hasnyálmirigy-sebészet általánossá válását viszont manapság még sok, itt nem részletezhető körülmény korlátozza. A pankreászrákok vonatkozásában a MIS lassúbb előretörésének van néhány speciális oka is: a MIS módszerekkel megoperálható korai - többnyire T1, legfeljebb T2 - stádiumban felismert, low-grade daganatok aránya nagyon alacsony; a mütéti idő többszöröse a nyílt mütétének (5,5-12 óra!); az átlagosnál sokkal gyakoribb konverzió (40\%) pedig ergonómiailag is nagyon ,gazdaságtalan”, mert sokszor válik elkerülhetetlenné a mütét már nagyon elörehaladott fázisában. A kórházi ápolási idő sem szól a MIS-technika választása mellett, mert kezdettől szinte azonos a nyílt mütétekével ${ }^{9}$.

A hasnyálmirigyrák sebészetének terjedését az is akadályozta, hogy csonkoló mütétek kezdeti eredményei meglehetősen lehangolóak voltak. A rendkívül magas szövődmény- és mortalitási arány miatt sokáig a PD mint mütét létjogosultságának még az erkölcsi alapjait is megkérdöjelezték. Erre a szkepticizmusra mi sem jellemzőbb, mint hogy még 1970-ben (!) is megjelen(hetet)t olyan közlemény, amely a reszekábilis esetekben is a palliatív meg- 
oldás elsőbbsége mellett érvelt. ${ }^{10}$ A sebészi technika csak az 1980-as évekre fejlődött arra a szintre, hogy az akkori közleményekben már bizonyítékalapú (EBM) adatokkal tudták alátámasztani a pankreászrák mütéti kezelésének fontosságát. ${ }^{11-13} \mathrm{Az}$ amerikai rákregiszter az ezredforduló táján igazolta, hogy a pankreásztumoros betegeknek, akik radikális mütétre kerültek, az összesített 5 éves túlélési esélye 15-25\%-os, míg mütét nélkül ez csak 1-5\%-ra tehető. ${ }^{14,15}$ Valószínü azonban, hogy a reális túlélési esély még ennél is szerényebb, egyes szkeptikus szerzők szerint teljes gyógyulás reálisan csak 1-2\% körüli arányban remélhető. ${ }^{16}$

Az Üllői úti Sebészeti Klinika ennek a szakmatörténeti folyamnak mindig az élvonalában járt. Szabó Elemér doktor 1931-es közleménye a Klinika kő nélküli mechanicus sárgaságos eseteiről szól, s ebben 37 hasnyálmirigyrák esetét is feldolgozza; majd ezután 1943-ban dr. Nánay Andor újabb 54 beteg esetét elemzi. Az összesen 91 kórtörténet szomorú következtetései közül kiemelendő, hogy „,az első panasz/tünet megjelenése és a diagnózis között középértékben 8 hónap telik el”, illetve, hogy „,bár annak az elgondolásnak kell vezetnie bennünket, hogy a daganatot lehetö gyökeresen távolítsuk el, sajnos a hasnyálmirigy-fejrákok esélyei úgy a mütéti halálozás, mint a mütét késői eredményét illetően nem jók". A beavatkozások halálozási aránya ebben az időszakban a Klinikán $25,4 \%$ volt, ami „kb. egyezett a többi statisztikák számadatával". ${ }^{17}$

A Klinika vezetésével 1949-ben megbízott Hedri Endre professzort a magyar szervezett baleseti sebészeti ellátás egyik megteremtőjeként említik, és személyes érdeklődése a gasztroenterológiai sebészeten belül először ugyan a kolorektális daganatokra irányult, ám a korszerü hasnyálmirigy-sebészet fejlődésének az elindítójává is vált azzal, hogy hazánkban elsőként végzett sikeres PD-t. 1961-ben e témáról tartotta a Balassa Emlékelőadását is.

Mint az általános történeti összefoglalásból is kitünik, a hasnyálmirigy sebészetének mütéttechnikai fejlődése a XX. század harmadik harmadában felgyorsult: a standardizálódó technikák birtokában az egyre nagyobb esetszámokat koncentráló („high-volume”) centrumokban a mütéti eredményesség ugrásszerűen javult: mára gyakorlott munkacsoportoktól elvárt alapkövetelmény az 5\% alatti korai mütét utáni halálozási mutató. Klinikánkon ez hosszú távon $3 \%$ körül alakul.

A technikai újításokhoz két nemzetközi tekintetben figyelmet érdemlő közléssel csatlakozott a Klinika. Egyik Pataky Zsigmond nevéhez füződik, s mára kissé feledésbe merült, ${ }^{18}$ a másik azonban „szerzői névvé” nemesülve vonult be a köztudatba: Flautner Lajos professzor 1985-ös közleményét a pancreato-gastricus anasztomózisró ${ }^{19}$ ma is alapmüként idézik. A szakmatörténti adatok azt is mutatják, hogy a minimálisan invazív sebészi technikák számára a hasnyálmirigy mint „célszerv” más szervekhez képest sokkal nehezebben hozzáférhető. Ennek tudható be, hogy a MIS-technikák is jelentős késéssel épültek be a pankreászsebészetbe, ám a Klinika Tihanyi Tibor professzor vezetésével ebben is élenjáró volt: a Magyar Gasztroenterológiai Társaság (MGT) 1998-as, 40. Nagygyülésének fötémákról szóló kerekasztalülésén már 13 disztális laparoszkópos reszekciót ismertetett, ami az első ilyen beszámoló volt Magyarországon.

Ugyancsak még a 60-as évek elején, Hedri professzor vezetői működése idején alapozódtak meg azok a szakmaközi kapcsolatok, amelyek az emésztőszervek betegségeinek egyre komplexebb ellátását teszik lehetővé: a belgyógyász és sebész alapképzettségü gasztroenterológusok, endoszkópos szakemberek együttmüködése, majd az eredetileg diagnosztikus céllal használatba vett ultrahangos képalkotó technika invazív beavatkozásokat is megteremtő fejlődése mára elmossa a sebészi és nem sebészi pancreatológia határait. Az együttmüködés kezdete 1960-ra tehető, amikor a parádfürdői Gasztroenterológiai Orvosgyülés fötémája volt $A$ hasnyálmirigy kórtana és klinikuma, amelynek keretében a sebészi referátumot Hedri Endre professzor tartotta.

A következő nagyobb lendületet a klinikai hasnyálmirigy-sebészeti profil Szécsény Andor igazgatása idején kapta: maga is kiváló pankreászsebészként érzékelte, hogy a szerv sebészete világszerte feljövőben van, ugrásszerü fejlődés előtt áll. Az 1970-ben tudományos aspiránsként a Klinikára került Flautner Lajos szakmai érdeklődése kezdettől elsősorban erre a szervre irányult, így Szécsény professzor őt szemelte ki profilvezetőnek: ennek nyomán kb. az évtized végétől a Klinikán is külön munkacsoportok foglalkoztak az akut pankreatitisz (AP), a krónikus pankreatitisz $(\mathrm{KP})$, valamint a tumorok $(\mathrm{PTu})$ sebészi ellátásának kérdésköreivel. Az AP ellátásában fö kérdéssé az - esetleges - invázió/mütéti ellátás megválasztása és idejének optimalizálása vált, a KP-val összefüggésben a műtéti ellátás késői eredményei és a szervmegtartó megoldások lehetőségei kerültek fókuszpontba, míg a sebészi onkológia továbbra is a szükséges/elégséges radikalitás problémakörét feszegeti. Mindehhez társult a mütétre szoruló betegek teherbírásának a perioperatív ellátásban elérhető fokozására, javítására irányuló törekvés, hiszen jobb teherbírású betegeken a sebészi eredményesség is jobb lehet. A közös szemlélet, közös munka eredményeképp a különféle interdiszciplináris együttműködések eredményeivel foglakozó kongresszusokon, ezeken belül kiemelten az MGT Nagygyülésein egyre gyakrabban szerepel a pankreatológia kiemelt témaként: így 1991-ben, 1993-ban, 1998-ban, 2003-ban. ${ }^{20}$ A Klinika pénteki napokra szervezett, országos hatáskörü hasnyálmirigy-szakrendelésére egyre nagyobb számban áramlottak a betegek; ebben az időszakban vált általánossá, hogy évente már 300-400 pankreászmütétet végeztünk, ami európai léptékben is nagy centrummá tette az I. sz. Sebészeti Klinikát. Ekkor alakultak ki nemzetközi kapcsolataink nagy európai központokkal, közöttük Ulmmal, Heidelberggel, Lunddal, Milánóval stb. 1998-ban a pankreászsebészet ismét a Balassa Emlékelőadás témájaként szerepelt: Flautner professzor a téma 150 éves fejlödéstörténetét tekintette át.

A diagnosztikus és társszakmák fejlődése persze azt is magával hozta, hogy időről időre más betegcsoportok kerültek a súlypontba. Az 1970-es évek végétől ismét elsődlegesen sebészi betegségnek tekintett AP kezelésé- 
ben például ismét a nem sebészi elvek tértek vissza, míg a legutóbbi évtizedben kifejezett figyelem irányul az ún. borderline vagy a priméren irreszekábilisnak ítélhető tumorok neoadjuváns jellegủ kemoterápiájára. Az AP ellátásának változását jól példázza, hogy 1993-ban $d r$. Magyar Ambrus 10 év alatt elvégzett kb. 1000 pancreas-pseudocysta mütétről számolt be az MGT Nagygyülésén, és készíthetett erről monográfiaértékủ disszertációt, mára ennek a betegcsoportnak az ellátása szinte kizárólag az invazív gasztroenterológia feladatává vált, s ezt a tevékenységet Klinikánkon is belgyógyász-gasztroenterológus kollégáink vették át. ${ }^{21} \mathrm{~A} \mathrm{KP}$ endoszkópos és gyógyszeres kezelésének - föleg hosszú távú - eredményei is lassan felzárkóztak a mütéti eredmények mellé, ezért e betegek száma is csökkenő. Folyamatosan növekvő viszont a daganatos mütétek száma. A PTu sebészetének fejlődését egyébként már több évtizede nemzetközi együttműködésben végigvitt multicentrikus vizsgálatok eredményei alapozzák meg. Ezek a klinikai tanulmányok főként a kiterjesztett radikalitás, valamint a sebészi és nem sebészi onkológiai kezelések különböző kombinációinak hatékonyságát vizsgálják. A Klinika természetesen ezekbe az együttmüködésekbe is korán bekapcsolódott és nagy esetszámaival jelentősen hozzájárul a tanulmányok eredményeihez. ${ }^{22}$

A sebészi pancreatológia hatékonyságát fokozó táplálásterápia - „mesterséges táplálás” - úttörő kezdeményezése is a reszekciós műtétre kerülő betegcsoportok megfigyelésén alapult. ${ }^{23} \mathrm{~A}$ kísérletes eredményekkel elökészített, transzlációs jellegü, s nemzetközi összevetésben is elsők között alkalmazott szupportív ellátás mára kezelési irányelvi alapelemmé vált. ${ }^{24}$

A Klinikán felgyülemlett hasnyálmirigy-sebészeti tapasztalatot sok, elsősorban fiatal szakember átvette az elmúlt évtizedekben. A hazai pankreászsebészet vezetői pedig többnyire azok közül kerültek ki, akik hosszabb-rövidebb időt töltöttek a Klinika mütőiben, s részben vagy egészben itt végezték a tudományos minősítésüket megalapozó vizsgálatokat.

$$
* * *
$$

A múlt fenti rövid áttekintése után adódik a kérdés: mi lehet a további fejlödés iránya? Egy biztos: a jelen infrastrukturális, személyi és finanszírozási feltételek között az esetszám nem emelhető. A hatékonyság javításának alapja a pontosabb, daganatstádium szempontjából sokkal korábbi diagnosztika. Ennek reményét nem elsősorban a képalkotás minőségi javulásától, hanem alternatív, új diagnosztikus módszerektől remélhetjük: ilyen lehet például az ún. „liquid-biopsziák” kifejlesztése. Ez az eljárás vérben vagy egyéb testnedvekben jelen lévő biomarkerek kimutatását jelentené; nyilvánvaló, hogy ehhez új szakmákkal való együttmüködések kifejlesztése szükséges. Az első lépéseket megtettük; ${ }^{25}$ hasonló „,bátor” együttmüködésekre lesz szükség. A sebészi tevékenység hatékonyságát - elviekben - javíthatja a MIS-technikával végzett beavatkozások arányának emelése is, a fentebb áttekintett speciális okok folytán azonban ennek rohamos terjedése egyelöre saj- nos nem remélhető. A nem daganatos betegségekben (AP és KP), valamint az irreszekábilis PTu esetekben viszont még jobban előtérbe kell kerülnie az invazív endoszkópos megoldásoknak, amelyeknek nemcsak a drágább, időigényesebb, hosszabb felépülési idővel kísért mütéteket kell kiváltaniuk, hanem ráadásul hosszú távon is hatékonyabbaknak kell lenniük a sebészi módszereknél. Ezt a célt is szolgálja majd, ha 2020 szeptemberében kiteljesedik az I. sz. Sebészeti Klinika profiljának évekkel ezelőtt megindított bővítési folyamata: megnyílik a Klinikához kapcsolt Gasztroenterológiai Centrum. S egy speciális céllal készült rövid áttekintésben sem hallgatható el, hogy a hasnyálmirigy-betegségek kezelésének lehetőségeit, minőségét különösen érzékenyen befolyásolja a finanszírozás mértéke: ennek javítása nélkül a következő 111 év eredményei bizonyosan elmaradnának azt előzőétől...

\section{Irodalomjegyzék}

${ }^{1}$ Manninger $V$, Verebélÿ T: A sebészet tankönyve. III. Részletes sebészet. 2. A hasnyálmirigy (pankreas) sebészete. 1920 Mai Henrik és Fia Budapest 704-716.

${ }^{2}$ Whipple A, Parson W, Mullins C: Treatment of carcinoma of the papilla of Vater. Ann Surg 1935; 102: 763-779.

${ }^{3}$ Brunschwig A: A one-stage pancreaticoduodenectomy. SGO 1937; 65: 681-684.

${ }^{4}$ Halsted $W$ : Contributions to the surgery of the bile passages, especially the common bile duct. Boston Med Surg J 1899; 141: 645-654.

${ }^{5}$ McClusky DA, Skandalakis LJ, Colborn GL et al.: Harbinger or hermit? Pancreatic anatomy and surgery through the ages - part 3. World J Surg 2002; 26: 15121524.

${ }^{6}$ Lin PW, Lin YJ: Prospective randomized comparison between pylorus-preserving and standard pancreaticoduodenectomy. Br J Surg 1999; 86: 603-607.

${ }^{7}$ Bernheim BM: Organoscopy. Cystoscopy of the abdominal cavity. Ann Surg 1911; 53: 764-647.

${ }^{8}$ Gagner M, Pomp A: Laparoscopic pylorus-preserving pancreatoduodenectomy. Surg Endosc 1994; 8: 408-410.

9 Milone L, Turner P, Gagner M: Laparoscopic surgery for pancreatic tumors, an update. Minerva Chir 2004; 59: 165-173.

${ }^{10}$ Crile $G$ : The advantages of bypass operations over radical pancreaticoduodenectomy in the treatment of pancreatic carcinoma. SGO 1970; 130: 1049-1053.

11 Shapiro TM: Adenocarcinoma of the pancreas: A statistical analysis of bypass vs. Whipple resection in good risk patients. Ann Surg 1975; 182: 715-721.

12 Crist D, Sitzman J, Cameron J: Improved hospital morbidity, mortality, and survival after Whipple procedure. Ann Surg 1987; 206: 358-365.

${ }^{13}$ Trede M, Schwall G, Saeger H: Survival after pancreaticoduodenectomy: 118 consecutive resections without an operative mortality. Ann Surg 1990; 211: 447-458.

${ }^{14}$ Sener SF, Fremgen A, Menck HR et al.: Pancreatic can- 
cer: A report of treatment and survival trends for 100,313 patients diagnosed from 1985-1995, using the national cancer database. J Am Coll Surg 1999; 189: 1-7.

${ }^{15}$ Kuhlmann KF, de Castro SM, Wesseling JG et al.: Surgical treatment of pancreatic adenocarcinoma: actual survival and prognostic factors in 343 patients. Eur J Cancer 2004; 40: 549-558.

${ }^{16}$ Smeenk HG, Tran TCK, Erdmann $J$ et al.: Survival after surgical management of pancreatic adenocarcinoma: does curative and radical surgery truly exist? Langenbecks Arch Surg 2005; 390: 94-103.

${ }^{17}$ Nánay A: A hasnyálmirigy rákjáról. In: A Budapesti Királyi Magyar Pázmány Péter Tudományegyetem I. sz. Sebészeti Klinikájának dolgozatai Verebélyi Dr. Verebélÿ Tibor professor emlékére 1941-1942. Királyi Magyar Egyetemi Nyomda Budapest 362-370.

18 Pataky Zs, Popik E: Operative Modizifierung bei Pankreaskopf-rezektion. Chirurgie 1959; 30: 464.

${ }^{19}$ Flautner L, Tihanyi T, Szécsény A: Pancreatogastrostomy: an ideal complement to pancreatic head resection with preservation of the pylorus in the treatment of chronic pancreatitis. Am Surg 1985; 150: 608-611.

${ }^{20}$ Szalay F, Rácz I, Hunyady B. (szerk.): A Magyar Gasztroenterológiai Társaság 50 éves története. 2008. MGT Budapest
${ }^{21}$ Hritz I, Fejes R, Székely I et al.: Endoscopic transluminal pancreatic necrosectomy using a self-expanding metal stent and high-flow water-jet system. World J Gastroenterol. 2013; 19(23): 3685-3692.

22 Influence of Resection Margins on Survival for Patients With Pancreatic Cancer Treated by Adjuvant Neoptolemos JP and the members of the European Study Group for Pancreatic Cancer: Chemoradiation and/or Chemotherapy in the ESPAC-1 Randomized Controlled Trial. Ann Surg. 2001; 234(6): 758-768.

${ }^{23}$ Bodoky Gy, Harsányi L, Pap Á, Tihanyi T, Flautner L: Effect of enteral nutrition on exocrine pancreatic function. Am Journal of Surg 1991; 161: 144-149.

24 Weinmann A, Braga M, Harsányi L, Laviano A, Ljungqvist $O$, Soeters $P$ : ESPEN guidelines on enteral nutrition: surgery including organ transplantation. Clinical Nutrition 2006; 25(2): 224-244.

25 Osteikoetxea X, Benke M, Rodriguez $M$ et al.: Detection and proteomic characterization of extracellular vesicles in human pancreatic juice. Biochemical and Biophysical Research Communications 2018; 499: 37-43.

A cikk a Creative Commons Attribution 4.0 International License (https://creativecommons.org/licenses/by/4.0/) feltételei szerint publikált Open Access közlemény, melynek szellemében a cikk bármilyen médiumban szabadon felhasználható, megosztható és újraközölhetö, feltéve, hogy az eredeti szerző és a közlés helye, illetve a CC License linkje és az esetlegesen végrehajtott módosítások feltüntetésre kerülnek. (SID_1) 